\title{
Changing mental maps of the Baltic Sea and Mediterranean regions
}

\section{Janne Holmén}

To cite this article: Janne Holmén (2018) Changing mental maps of the Baltic Sea and Mediterranean regions, Journal of Cultural Geography, 35:2, 230-250, DOI: 10.1080/08873631.2017.1401405

To link to this article: https://doi.org/10.1080/08873631.2017.1401405

(c) 2017 The Author(s). Published by Informa
UK Limited, trading as Taylor \& Francis
Group

Submit your article to this journal $₫$

Џلll Article views: 257

Q View related articles ¿

View Crossmark data $₫$ 


\title{
Changing mental maps of the Baltic Sea and Mediterranean regions
}

\author{
Janne Holmén (10) a,b,c \\ ${ }^{\mathrm{a} D e p a r t m e n t ~ o f ~ H i s t o r y, ~ U p p s a l a ~ U n i v e r s i t y, ~ U p p s a l a, ~ S w e d e n ; ~}{ }^{\mathrm{b}}$ Faculty of Arts, Psychology and \\ Theology, Åbo Akademi University, Åbo, Finland; ' Institute of Contemporary History, Södertörn \\ University, Huddinge, Sweden
}

\begin{abstract}
Little empirical research has considered the way in which macro-regions are perceived outside academic and political circles. Such studies alone can determine what regional narratives mean for the wider public, and the extent to which they coincide with region-building images produced by elites. This article examines the mental maps of high school seniors in 10 cities in the Baltic Sea and Mediterranean regions, focusing upon their perception and knowledge of other countries in those areas. Despite efforts at region building since the Cold War, the two regions remain divided on mental maps. Students have little knowledge of countries across the sea from their own, although such knowledge is generally greater among those from coastal (and particularly island) locations. A comparison with maps constructed by Gould in 1966 reveals that the perception of countries within one's own region among Italian and Swedish students has become more negative over the last 50 years.
\end{abstract}

KEYWORDS Macro-regions; circum-maritime regions; spatial information; geographic perception; region-building; mental maps

\section{Introduction}

In 1975, Yi-Fu Tuan claimed that, despite their recent origin, nations had become very real places to citizens through politics and the propaganda machinery of national governments. On the other hand, regionalism was only promoted by a few writers and artists, and was unlikely to impress broad layers of the population unless regions assumed political importance. However, since then, sub-national as well as macro-regions have attracted the increased attention of political elites. Little empirical research has investigated how macro-regions are perceived outside academic and political circles.

CONTACT Janne Holmén $\otimes$ janne.holmen@hist.uu.se $\Theta$ Department of History, Uppsala University, Trädgårdsgatan 3A, 75126 Uppsala, Sweden

(c) 2017 The Author(s). Published by Informa UK Limited, trading as Taylor \& Francis Group

This is an Open Access article distributed under the terms of the Creative Commons Attribution-NonCommercial-NoDerivatives License (http://creativecommons.org/licenses/by-nc-nd/4.0/), which permits non-commercial re-use, distribution, and reproduction in any medium, provided the original work is properly cited, and is not altered, transformed, or built upon in any way. 
Such studies alone can determine what regional narratives mean for the wider public, and the extent to which they comply with region-building images produced by elites. This article examines the mental maps of high school seniors in 10 cities in the Baltic Sea and Mediterranean regions.

Seas and waterways are generally perceived as constituting the borders between countries or regions, although there have been historical periods when central seas have served as means of unification. In recent decades, several concurrent political and technological developments have had the potential to alter the image of the Mediterranean and the Baltic Sea as barriers on mental maps. Whether this has in fact taken place remains an open question. There is no doubt that such a development would be considered desirable by political leaders and scholars, who have tried by various means to bring about the consolidation of regions around these seas. History has traditionally been written within a national framework, but the appearance $\mathrm{La}$ Méditerranée et le monde méditerranéen à l'époque de Philippe II by Fernand Braudel in 1949 marked the beginning of regional history writing, and similar attempts were made with regard to the Baltic Sea region by scholars such as Klinge (1995) and Gerner et al. (2002) after the Cold War. On the political level, regional organizations and parliaments such as the Euro-Mediterranean Partnership, the Parliamentary Assembly of the Mediterranean, and the Baltic Sea Parliamentary Conference have been increasing their activity over the past few decades, and have dealt with questions of trade and environmental protection. The attempts to revive a medieval trading organization through the New Hansa were an effort to combine historical and economic region building. All of these are attempts to foster a sense of regional connection united, rather than divided, by the large seas at their core.

By surveying students in their last year of secondary school in the Baltic Sea and the Mediterranean regions, we hope to establish whether the Mediterranean and the Baltic Sea serve to connect or divide regional perceptions on students' mental maps. We used a survey to determine student knowledge and attitudes regarding different countries in these regions. ${ }^{1}$ By comparing the survey results from 2014 to 2015 with similar studies conducted in the 1960s, the present study also attempts to ascertain whether attitudes toward countries in those regions have changed in the intervening period.

\section{Mental maps}

The concept of a "mental map" has been introduced to describe how people orient themselves within their environment and how they perceive the world, and is approximately synonymous with the idea of cognitive maps. Although both terms are used in geography, behavioral science and psychology, the term "mental maps" is more common among geographers (Hannes et al. 2012). The term mental map has recently also been used by historians 
in attempting to describe the worldviews of political leaders (Casey and Wright 2008, 2011), the French colonial mind (Thomas 2011), or images of the region around the Baltic Sea (Götz et al. 2006). Little communication has so far taken place between those engaged in the historical and geographical research on mental maps. The elaborate methods and definitions developed by geographers have not reached historians, and the interest of historians in how political developments contribute to changes in mental maps has so far not reached geographical researchers. This article will attempt to combine the strengths of both approaches to mental mapping by studying the historical question of change over time using methods developed in the field of geography.

The term mental map might refer to one of two things: the images of the surrounding world that people hold in their minds, and an actual map which a researcher has constructed in order to represent the worldview of his research objects. The term is used here to describe maps the author has constructed on the basis of survey data. These maps do not represent the mental map of a single individual, but an average of the maps of a group of people.

The pioneer of the survey method in mental map research was the geographer Peter Gould. From the mid-1960s on, he investigated student knowledge and perception of areas such as US states (1966), municipalities in Sweden (1975a), and countries in Europe (1966) by constructing information and perception maps. While Gould recognized that his definition and measurement of information was grossly simplified, he claimed that such simplification was inevitable at the beginning, but could lead to the exploration of more complicated questions (1975b, p. 88).

Gould believed that the mental maps of those living in a certain place resulted from information flows. The closer a place was, and the larger its population, the more information people received about it and the more prominent it became on their mental maps. However, barriers to information flow (political, such as national borders, or natural, such as mountain ridges or waterways) could alter this picture (Gould and White 1974, pp. 141-143). When launched, the model seemed very simplified. For example, it ignored Galtung's (1971) suggestion that the direction and strength of global information flow are also affected by post-colonial center-periphery relations. Today, in the information age, the view of individuals as passive receivers of information flow seems even more oversimplified, as it is likely that the importance of active information-seeking has increased. Since Gould conducted his research, information-seeking behavior has become a well-established field of research within library and information science (Case 2002).

Gould also found that people living in different locales generally agreed on which places they considered attractive to live in, with the exception of the "local dome of preference", i.e. the particular attractiveness of nearby locations. However, Gould found that not all of their neighbors were positively perceived. The great quantity of information respondents had about 
nearby locations enabled them to better discriminate between nearby places than a distant observer was able to do. For example, people in the US living in the South were found to draw strong distinctions between positively and negatively perceived southern states, all of which seemed equal to observers from the North (Gould and White 1974, p. 100).

Mental mapping research experienced a peak from the 1960s to the 1980s, after which even Gould had exhausted his interest in the field. However, it is relevant to revisit his methods today because the geographers who conducted mental mapping research in that era primarily sought to discover general principles and regularities in mental maps. From the point of view of a historian, their empirical results are the mental maps of a particular period in time, shaped by its special political and social circumstances. In that respect, old mental mapping research is an important source to help us understand the worldviews of the 1960s, for example. When we do similar studies today, we can discover how present mental maps differ from older ones, and inquire into how and why mental maps change. Issues of how permanent mental maps are, and how they are transformed by historical developments, remain questions barely addressed by the first generation of mental mapping researchers.

\section{Waterways on mental maps}

Several writers in the field of mental mapping have discussed the functions of seas and other waterways on mental maps. Lynch (1970) observed that the strongest edges - linear elements usually forming boundaries between areas - on peoples' images of cities were visually prominent and difficult to cross. Many of the examples he cited were rivers or waterfronts. In a survey of 10,000 Swedish schoolchildren, Gould found that lakes were effective barriers to information flow as, for example, in Skövde, located between the two large Swedish lakes of Vänern and Vättern (1975a, p. 84). The area on the opposite shore of Lake Vättern was as unknown to the children as the interior of northern Sweden. Hägerstrand (1953) also found that lakes were contact barriers in rural Swedish districts. He attributed this to the dominant role that roads have played since the advent of automobiles, although he believed that lakes still had a connecting function in the early 1900s.

Also, a remote sea might serve as an important divide between geographical regions on mental maps. When Mozambican Islanders were asked to draw world maps, the Mediterranean was the sea most represented. Madaleno interpreted this as reflecting the knowledge that the Mediterranean separates Europe from Africa (2010, p. 119). The Eurobroadmap project, based on a worldwide survey of 9000 students in 18 countries, also found that the Mediterranean (especially its western parts) formed a sharp divide between perceived regions on mental maps (Didelon et al. 2011). Geographical research 
on the effects of waterways on mental maps has gained good insights into the present situation by utilizing survey instruments or quantitative methods, but they have not investigated changes in mental maps over time. However, like Hägerstrand, individuals have speculated as to what the situation might have looked like in the past. Although the mental map concept has not achieved the same level of theoretical understanding and methodological development among historians as it has among geographers, historians have attempted to investigate changes of mental maps to a greater degree.

According to Jackson (2009), medieval Scandinavians divided the world into four quarters: Sweden and all the lands to the east of the Baltic Sea on the route to Constantinople belonged to the eastern quarter, called Austrvega. In the thirteenth century, however, the designated region was narrowed to the lands on the South and East coasts of the Baltic Sea. Thus, the Baltic Sea was a central waterway for the eastern quarter of the world during the maritime early middle ages, but it became a dividing line between quarters with the advent of earth-bound feudal society.

A similar shift was seen in the early 1800s, when the map of Northern Europe was redrawn after Sweden lost Finland to Russia and gained Norway from Denmark (Berg 2014). In the process, the Baltic Sea, Skagerak, and Kattegatt were transformed from central hubs of the Nordic monarchies to defensive borders. In order to gain legitimacy for the change, rulers and scholars stressed the "naturalness" of the new borders, reinterpreting the mountain ridge that separated Sweden and Norway as a unifying "flowering meadow".

Earlier research confirms that the role of waterways on mental maps has shifted during political, technological, and social revolutions. This raises the question of how the developments of recent decades - such as the fall of the Iron Curtain, region-building efforts, and advances in information technology - have influenced the mental maps of the Baltic Sea and Mediterranean regions.

\section{Research question}

When the Cold War ended in the early 1990s, the Baltic Sea ceased to be the nearly impenetrable Iron Curtain it had been since the late 1940s. In the 1990s, scholars and politicians made attempts to strengthen the regional identity of the Baltic Sea region by talking it into existence (Götz 2016). More than two decades later one might have expected that region-building efforts in the area would have ended or at least weakened the Baltic Sea's role as a sharp divide between positively and negatively perceived places.

Attempts at region building have also been made in the Mediterranean, but with limitations regarding free movement. While the Mediterranean continues to function as an avenue for immigrants and refugees fleeing conflict 
zones, European nations have tried to reinforce the sea's properties as a barrier between continents by, for example, patrolling the sea and targeting migrant smugglers. Since the turn of the millenium, nationalistic and ethnocentric populist movements have gained support globally, including in the countries surveyed. By depicting foreigners as others against whom they want to draw distinct barriers such political movements has probably affected mental maps of foreign countries and people on the other side of the sea. In recent years, the aftermaths of the Arab Spring and tensions in Eastern Europe have also disturbed region-building in the Mediterranean and Baltic Sea regions.

The past few decades have also seen an increase in ferry and air traffic, enabled in the Baltic by the fall of the Iron Curtain, and in the Mediterranean spurred on by tourism and the rising number of North African expatriates in Europe, who frequently travel between their new and old homelands. Global sea transportation has quadrupled from 1992 to 2012 (Tournadre 2014). An even more revolutionary development has taken place in the field of electronic communications. According to Sassen, the Internet heralded the beginning of a post-national world in which physical borders and distances are of less importance than ever before (2002, p. 277). If correct, this would alter the degree to which seas are perceived as barriers. Thus, both theoretical arguments and parallels to the findings of earlier research make it likely that these developments have affected the mental maps of the two regions as held by their inhabitants. However, exactly what these mental maps look like after these transformations can only be determined through an empirical investigation.

The following pages will first examine to what extent the Baltic Sea and the Mediterranean function as either barriers or facilitators of information flow, based on the knowledge the people living around those seas have about areas on the opposite shore. Second, what people think about countries situated around the mutual sea that adjoins them will be investigated, including whether neighboring countries are incorporated in a regional dome of preference, regarded with indifference, or negatively perceived. We will also consider whether a change has taken place in such preferences since Gould surveyed the image of Europe among Swedish and Italian students in the 1960s.

\section{Method}

The results of the present study are represented by geographical information and geographical perception maps based upon data from surveys. Thus, information and perception are here used in a simplified way, to refer to the quantitative data that students produced in answers to the questionnaire described below. 


\section{The questionnaire and maps}

The geographical information map is based on the first question: the respondents were given a blank sheet of paper and asked to, in five minutes, write down as many place names as possible, freely chosen without geographic limitations as to scale, type of place, or region. We then coded these place names by country, and constructed choropleth maps based upon that country's percentage among all the place names mentioned.

The geographical perception maps are based on the second question: students were asked to rank each country on a blank map that included the areas in Figure 4 on a scale from one to five, with five indicating areas where they would most want to live. The map encompassed Europe and North Africa, thus including the Baltic Sea and Mediterranean regions. Based on the average of the points awarded each country, maps were constructed illustrating the perception of the students. Countries which were ranked by fewer than five students in a class were left blank on the map.

In 1966, Gould conducted a study of the perception of Europe among university students in European cities, including Uppsala and Rome. Using a map of Europe, he asked the students to order the countries beginning with the one in which they would most like to live. The existence of Gould's study enables a comparison of how the perception of Europe in Italy and Sweden has changed from 1966 until the present. However, since the political map of Europe has altered since 1966, it is not possible to exactly duplicate Gould's method. Therefore, a method suggested by Thill and Sui was used (1993). They have argued that ranking countries on a scale from 1 to 5 captures the middle range of moderate preferences more exactly than ranking 40 countries in order from 1 to 40, as in Gould's surveys. However, Thill and Sue concluded that the results of both methods were similar, which makes a comparison of this study's results and those of Gould meaningful.

\section{The selection of schools and the conduct of the surveys}

The schools surveyed were chosen to enable an investigation of the mental maps of the Baltic Sea and Mediterranean regions held by students living in different locations in relation to these seas. Since the purpose of the study was to investigate to what extent the Mediterranean and Baltic Seas function as barriers on mental maps, we surveyed students in locations on both sides of the former Iron Curtain in the Baltic Sea and on both sides of the continental divide between Europe and Africa in the Mediterranean. We selected schools to ensure a variety of locations in relation to the sea in question - inland, coastal, and island locations. Since differences between central and peripheral locations within each nation might affect the results but was something we did not intend to study, capitals were avoided. A total of 10 locations were 
selected: one on an island in the middle of each of the seas as well as two to the north and south for the Mediterranean or east and west for the Baltic Sea region, one on each side of the sea, one on the coast, and one inland: Fez and Tangier in Morocco, Malta, Venice and Bologna in Italy, Uppsala and Gävle in Sweden, the Åland Islands (belonging to Finland), and Noarootsi and Valga in Estonia. The inclusion of Swedish and Italian locations enables a comparison with Gould's 1966 survey.

Differences in school systems among the countries surveyed complicated the study. Educational diversity within each country has also increased over the last few decades, as schools have striven to develop specialized profiles with, for example, language or sports classes. However, the strong similarities between this study's maps of Swedish students, for example, and those found in the Eurobroadmap project (Grassland 2012), which surveyed a much larger number of students, suggest that the present study surveyed classes that were typical. However, the primary aim of this study was not to determine national representativeness, but to investigate the effect of different locations on the mental maps of the Baltic Sea and Mediterranean regions. Despite diversity, the basic similarity of school institutions worldwide makes them ideal for comparisons between countries as different as, for example, Estonia and Morocco.

With regard to age differences, students in Malta have already begun college at an age when other students in the survey are in the last year of secondary school. Therefore, Maltese first-year college students were surveyed. On Åland, students in the junior year of secondary school were surveyed, since those in their senior year were preoccupied with final exams. In Noarootsi, last-year students were combined with first-year students in order to get a sufficiently large sample (Table 1). Our sample size, one class at each location, is similar to the one used in many previous mental mapping research (such as Gould 1966). That the findings of these smaller studies are congruent with the ones based on much larger samples, such as Eurobroadmap or Gould (1975a), does indicate that a class size sample is sufficient in order to provide relevant results.

\section{Results}

\section{Geographical information}

Students from the western European mainland (Italy and Sweden) displayed little knowledge of countries on the other shore of their bordering seas. The most extreme example was in Uppsala, where no one cited a single Russian place name. Sweden's neighbor, Finland, was better known than Russia and the Baltic countries, but Uppsala students still knew more about Spain, Turkey, and France than they did about Finland (Figure 1). ${ }^{2}$ 
Table 1. Classes surveyed.

\begin{tabular}{|c|c|c|c|c|c|c|}
\hline Place & Date & Size & $\begin{array}{c}\text { Grade in upper } \\
\text { secondary } \\
\text { school }\end{array}$ & $\begin{array}{c}\text { Surveyed } \\
\text { during lesson } \\
\text { in }\end{array}$ & $\begin{array}{c}\text { Survey } \\
\text { language }\end{array}$ & $\begin{array}{c}\text { Profile/ } \\
\text { specialization of } \\
\text { school or class }\end{array}$ \\
\hline $\begin{array}{l}\text { Valga, } \\
\text { Estonia }\end{array}$ & $\begin{array}{l}1 \text { Apr. } \\
2015\end{array}$ & 30 & 3 of 3 & Estonian & Estonian & \\
\hline $\begin{array}{l}\text { Noarootsi, } \\
\text { Estonia }\end{array}$ & $\begin{array}{l}2 \text { Apr. } \\
2015\end{array}$ & 19 & 1 and 3 of 3 & Swedish & Estonian & $\begin{array}{l}\text { Boarding school, } \\
\text { Scandinavian } \\
\text { profile }\end{array}$ \\
\hline $\begin{array}{l}\text { Åland. } \\
\text { Finland }\end{array}$ & $\begin{array}{c}21 \text { Mar. } \\
2014\end{array}$ & 18 & 2 of 3 & Geography & Swedish & \\
\hline $\begin{array}{l}\text { Gävle, } \\
\text { Sweden }\end{array}$ & $\begin{array}{l}2 \text { June } \\
\text { and } 25 \\
\text { Aug. } \\
2014\end{array}$ & 31 & 3 of 3 & History & Swedish & $\begin{array}{l}\text { Cultural (theater, } \\
\text { dance, circus) }\end{array}$ \\
\hline $\begin{array}{l}\text { Uppsala, } \\
\text { Sweden }\end{array}$ & $\begin{array}{l}23 \text { Sept. } \\
2014\end{array}$ & 25 & 3 of 3 & History & Swedish & $\begin{array}{c}\text { Social science } \\
\text { program }\end{array}$ \\
\hline $\begin{array}{l}\text { Bologna, } \\
\text { Italy }\end{array}$ & $\begin{array}{c}11 \text { Nov. } \\
2014\end{array}$ & 23 & 5 of 5 & History & Italian & $\begin{array}{l}\text { Polytechnical } \\
\text { school (Istituto } \\
\text { tecnico) }\end{array}$ \\
\hline Venice, Italy & $\begin{array}{c}12 \text { Nov. } \\
2014\end{array}$ & 16 & 5 of 5 & English & Italian & Language school \\
\hline $\begin{array}{r}\text { Valetta, } \\
\text { Malta }\end{array}$ & $\begin{array}{r}16-17 \\
\text { Nov. } \\
2015\end{array}$ & 31 & Junior college & $\begin{array}{l}\text { Geography (on } \\
\text { a break) }\end{array}$ & English & \\
\hline $\begin{array}{l}\text { Tangier, } \\
\text { Morocco }\end{array}$ & $\begin{array}{c}25 \text { Nov. } \\
2015\end{array}$ & 18 & 3 of 3 & English & Arabic & Science class \\
\hline $\begin{array}{l}\text { Fez, } \\
\text { Morocco }\end{array}$ & $\begin{array}{c}23 \text { Mar. } \\
2015\end{array}$ & 41 & 3 of 3 & English & Arabic & \\
\hline
\end{tabular}

Students in Italian schools knew little about the southern and eastern parts of the Mediterranean region. France and Spain (3-6\% of the total number of place names) were the only Mediterranean countries about which they had substantial information (Table 2).

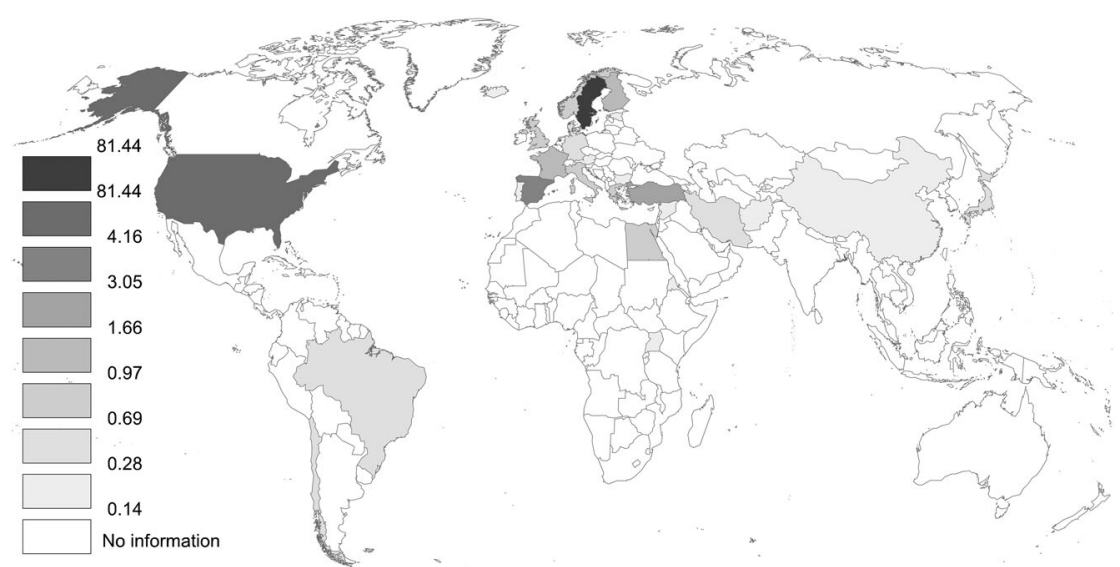

Figure 1. Uppsala information map displaying each country's percentage of the total place names mentioned by students. 
Table 2. Top 10 countries according to their percentage share of the total number of place names mentioned by students in each location.

\begin{tabular}{lrlrlllllr}
\hline Uppsala & $\%$ & Gävle & $\%$ & Åland & $\%$ & Noarootsi & $\%$ & Valga & $\%$ \\
\hline Sweden & 81.0 & Sweden & 69.0 & Sweden & 21.0 & Estonia & 50.0 & Estonia & 32.0 \\
USA & 4.2 & USA & 6.4 & Finland & 15.0 & USA & 4.0 & USA & 5.4 \\
Spain & 3.0 & Germany & 2.4 & Alland & 14.0 & Sweden & 3.1 & Latvia & 4.5 \\
Turkey & 1.7 & UK & 2.1 & USA & 7.2 & Russia & 2.7 & Germany & 3.4 \\
France & 1.1 & Italy & 2.0 & UK & 5.4 & Finland & 2.4 & Russia & 3.3 \\
Finland & 1.0 & France & 1.9 & Germany & 3.4 & Italy & 2.1 & Italy & 3.2 \\
Egypt & 0.8 & Norway & 1.8 & France & 3.2 & Latvia & 2.2 & Finland & 2.9 \\
Greece & 0.8 & Denmark & 1.2 & Italy & 2.8 & UK & 1.8 & Lithuania & 2.7 \\
Italy & 0.8 & Spain & 1.2 & Norway & 2.5 & Germany & 1.8 & UK & 2.1 \\
Norway & 0.7 & Greece & 1.1 & Russia & 2.3 & Norway & 1.6 & Sweden & 2.1 \\
& & & & & & & & & $\%$ \\
Bologna & $\%$ & Venice & $\%$ & Malta & $\%$ & Tangier & $\%$ & Fez & $\% 1.0$ \\
Italy & 57.0 & Italy & 20.0 & Malta & 21.0 & Morocco & 81.0 & Morocco & 20.0 \\
USA & 5.8 & USA & 9.8 & Italy & 10.0 & France & 1.8 & France & 4.2 \\
Spain & 4.1 & Spain & 5.7 & USA & 6.7 & Germany & 1.3 & USA & 3.8 \\
France & 3.1 & France & 4.8 & UK & 6.1 & USA & 1.3 & Spain & 3.1 \\
UK & 2.6 & UK & 4.0 & France & 4.3 & Spain & 1.1 & Germany & 2.6 \\
Germany & 1.6 & Australia & 2.7 & Germany & 3.5 & UK & 1.1 & Italy & 2.6 \\
China & 1.2 & Canada & 2.6 & Spain & 2.4 & Tunisia & 1.1 & Saudi Arab. & 2.6 \\
Portugal & 1.1 & China & 2.5 & Australia & 2.0 & Turkey & 1.1 & UK & 2.5 \\
Russia & 1.1 & Japan & 2.4 & Libya & 1.7 & Algeria & 0.8 & Sweden & 2.4 \\
Ukraine & 0.9 & Russia & 2.1 & Japan & 1.6 & Russia & 0.8 & Turkey & 2.3 \\
\hline & & & & & & & & & \\
\hline
\end{tabular}

Students in the two Estonian schools surveyed had a more detailed information map of Sweden than the Swedish students had of the Baltic countries. Likewise, the Moroccan students had more information of the northern shore of the Mediterranean than the Italians had of the southern shore. Moroccan students tended to have much more information about European countries in the western Mediterranean than about their North African neighbors. Their information maps show the North-South divide to be less important than the East-West divide.

In the island locations surveyed, Åland and Malta, knowledge of both shores of the sea was relatively good. Students on Åland had more information about Sweden than the Estonians and more information about all other countries around the Baltic Sea than the Swedes. Maltese students knew more about nearby Italy than they did about any other foreign country. In addition, Maltese students displayed significantly more knowledge of nearby Libya than any other group of students in the survey, and they knew a great deal about other Mediterranean countries as well. The Maltese also displayed considerable information about Cyprus, which, outside of Malta, was only mentioned by one student from Åland. However, the Ålanders' and Malteses' relatively good knowledge about the countries surrounding the two seas seems to be a reflection of their broader knowledge of maritime locations in general, and was not limited to the Baltic Sea and Mediterranean regions. This is illustrated by the example of Britain. Unlike the Italian students, the Maltese had more information about Malta's former colonial 
ruler, England, than about France and Spain. Students on Malta and Åland knew significantly more about England than students in any other location surveyed. As the central metropolis of a former maritime empire, England has for centuries been in contact with these island communities, which seems to have left a lasting impression on mental maps.

In both Sweden and Estonia, students from coastal schools knew more about the opposite shore than students from inland schools. The pattern that the other shore of the sea is better known in coastal locations holds true for Italy, where Venetian students had more detailed information maps of North Africa than Bolognese students. However, an exception to this rule was Tangier, where students had much less information about Spain than their counterparts from Fez, which is all the more surprising since under favorable conditions Spain can even be seen from Tangier. Only $1.6 \%$ of the place names mentioned by students from Tangier were Spanish, compared to $3.1 \%$ from Fez, 5.7\% from Venice, and 3\% from Uppsala. Some of the Spanish place names mentioned by Moroccan students are not situated north of the Straits of Gibraltar; Ceuta and Melilla, enclaves in Morocco, constitute one-third of the Spanish place names cited in Tangier and one-fifth in Fez. The area around the Gibraltar Straits, which encompasses a continental divide and multiple enclaves, might be described as an unusually complex borderscape. According to Rajaram and Grundy-Warr (2007), by excluding the chaotic outside, borders instill a sense of community, and in the process may produce hidden geographies. It is possible that the location of Tangier close to an ambiguous political border creates the need for a clear and distinct mental border, separating a well-known "us" from a "them", virtually forming a hidden geography. However, it has to be remembered that the Tangier sample is the least robust in this study, since class size was relatively small and the number of place names mentioned per student was low, contributing to a low total of placenames (Tables 1 and 2).

In summary, although the other shore of the sea was better known to those east of the Baltic Sea and south of the Mediterranean, and also on the islands, than in the western European mainland west and north of these seas, those bodies of water still seem to serve as barriers to information, albeit to a different degree depending upon where one resides. Thus, he information maps are not characterized by good knowledge about countries around the Baltic and Mediterranean seas. Instead, they are dominated by other traits.

The geographical information maps appear to be predominantly national. In Uppsala and Tangier, more than $80 \%$ of the place names mentioned by students were located in Sweden or Morocco, respectively. The other extreme was Venice, where only $20 \%$ of the place names listed by students were Italian. All classes had more than double the amount of information about their own nation than about any other country, with the exception of Åland, where Swedish place names constituted 21\%, mainland Finland 
$15 \%$, and Åland $13 \%$ of the total. This pattern might well be related to the island's historical and geographical location between Sweden and Finland; it is a monolingual Swedish-speaking autonomous province of Finland, which until 1809 was a part of Sweden.

While maps from most locations focused upon Europe and the US and left large parts of the globe (especially Africa) blank, almost all continents were well represented on the mental map from Fez (Figure 2).

According to Galtung's (1971) theory, the main direction of global information flows is from the center of the West to the periphery of the developing world, while much less information flows in the opposite direction. This would explain why the periphery, such as Fez, has more elaborate mental maps of the center than the other way around. However, another of Galtung's hypotheses, that there is little or no flow of information between peripheral countries, is contradicted by our finding that the most detailed mental maps of the periphery were, in fact, to be found in the periphery. This pattern is confirmed by data from the Eurobroadmap project. ${ }^{3}$ For example, it showed that Cameroonian students had much more elaborate mental maps of the peripheral parts of the world than Swedish students.

\section{Geographical perception}

In Gould's investigation of residential desirability in Europe from 1966, ${ }^{4}$ Swedes considered Greece and Portugal (with their then-authoritarian regimes) as unattractive as the socialist countries, while Italians perceived Greece more favorably. However, Italians ranked Finland, which Swedes almost placed on a par with Sweden, poorly. Gould interpreted the Italians'

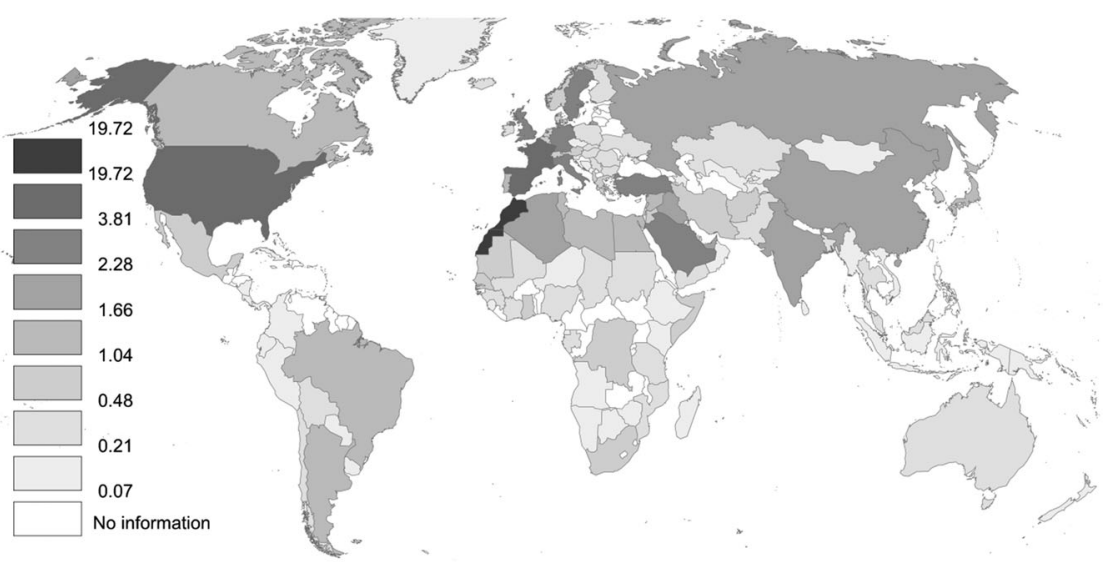

Figure 2. Fez information map displaying each country's percentage share of the total number of place names mentioned by students (1443). 
positive view of France, Spain, and Portugal as a preference for "Latin" countries, but since the positive view also encompassed Greece it might as well be described as a Mediterranean preference (Figure 3).

Our 2014-2015 survey makes it possible to investigate whether the Mediterranean preference of Italians have been strengthened in the intervening years, and whether the positive Swedish view of Finland, after the fall of the Iron Curtain and decades of attempted Baltic Sea region building, has developed into a general preference for countries in the region. From a regionbuilding perspective, the results are discouraging. In fact, the trend has been in the opposite direction. Notably, in 2014 Finland was more positively perceived in the Italian cities of Bologna and Venice than in the Swedish cities of Gävle and Uppsala (Figure 4). This also represents a change from 1966, when Gould found that Swedish university students had a more positive view of nearby Finland than students from other countries in Europe, including Italy (1966, pp. 27-51). A similar change has taken place regarding Sweden's other next-door neighbor in the Baltic Sea region, Denmark. In 2014, other than Italy itself, only two countries in the Mediterranean region (Spain and Greece) were perceived more favorably in Italy than in Sweden, and that only by a slight margin. Thus, Italians and Swedes seem to have experienced negative region building since the 1960s: today they are not particularly fond of their neighbors and would prefer to live in each other's regions rather than living in their own. This is clearly illustrated by Figure 4 .

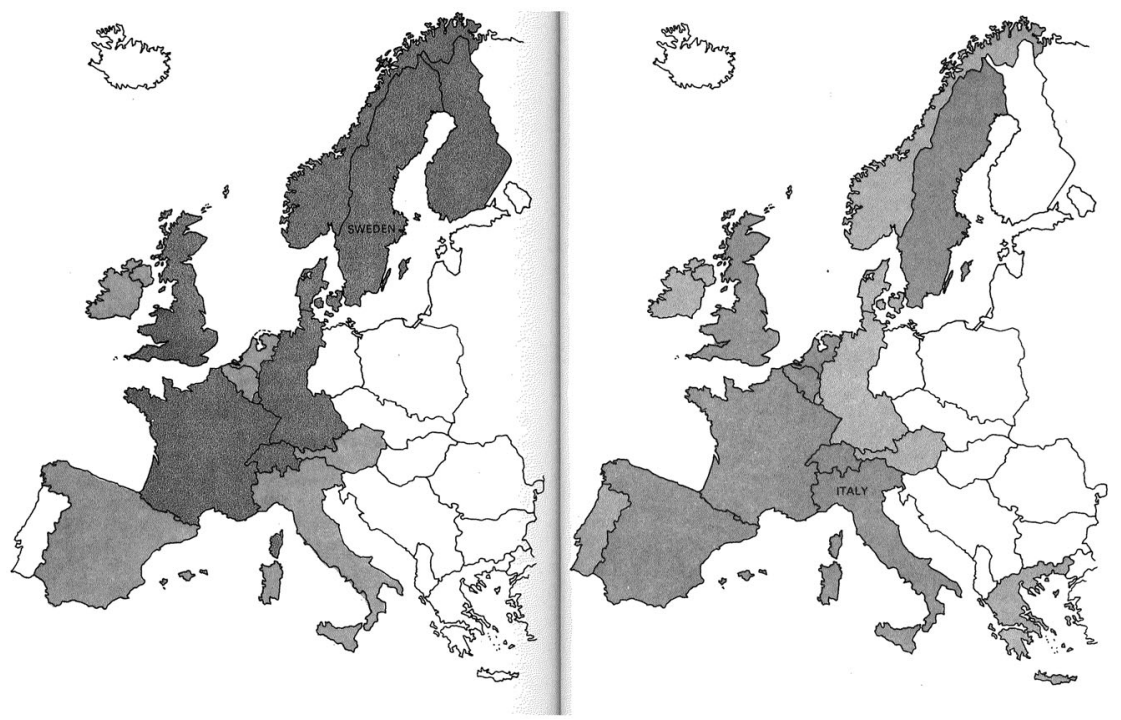

Figure 3. Residential desirability of European countries in 1966. Darker colors mean more positive perception. Perspectives of university students from Uppsala (left) and Rome (right). (Based on Gould and White (1974, pp. 182-183).) 


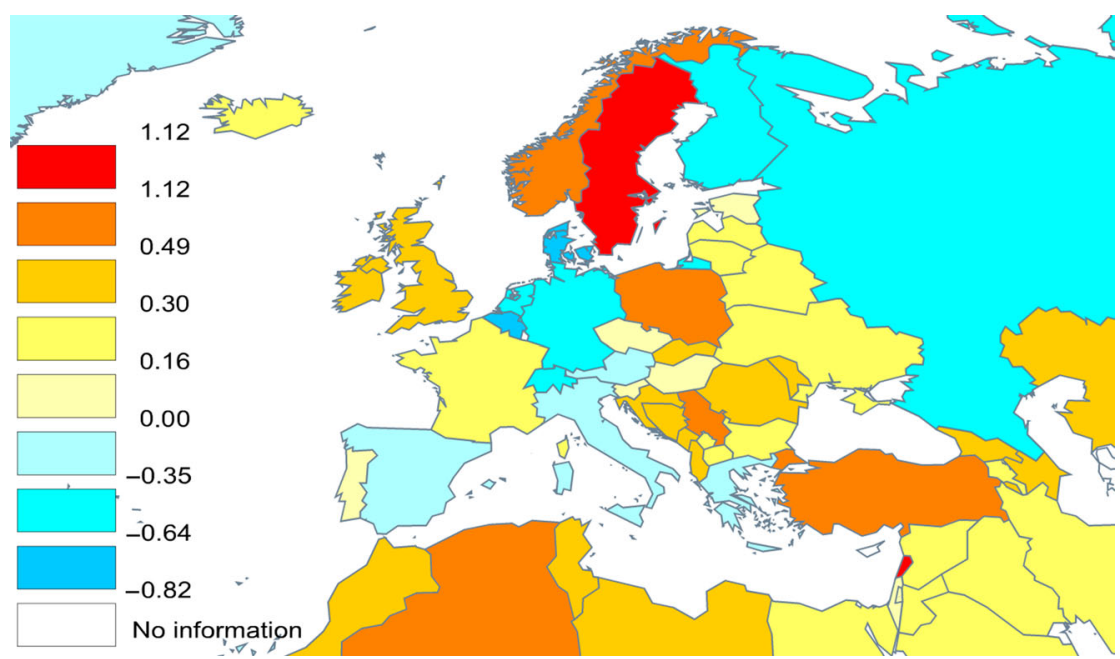

Figure 4. Aggregate map showing differences in perception between Swedish and Italian secondary school students in 2015. Map is constructed by subtracting averages in perception awarded by Italian students (Bologna and Venice) to each country on the map from averages as rated by Swedish students (Uppsala and Gävle). Red colors are more positively perceived in Sweden, blue in Italy.

This phenomenon is not limited to Swedes and Italians, but can be found in the other locations surveyed as well. The perception maps from those locations surveyed in 2014-2015 share the common feature that the countries on the eastern and southern fringes of the map are generally more negatively perceived, although the south is most negatively perceived by Mediterranean students and the east by students from the Baltic Sea. For example, in all the locations surveyed in the Mediterranean, students indicated they would prefer living in Russia to living in Algeria, while students from the Baltic Sea region preferred Algeria to Russia (Figure 5). This is the opposite of what one might expect if region building had been successful in building a regional consciousness and identity among residents around the Baltic and Mediterranean seas. It indicates that the rivalry among neighbors is stronger than local preference in these regions.

Within the Mediterranean region, the negative perception noted above cannot simply be explained by a sharp North-South divide between African and European countries. In 1966, most Italian students had a relatively positive view of nearby Albania, which they valued almost as highly as Finland. On the other hand, Albania was ranked at the bottom of the charts in the rest of Europe, including Sweden. In 2014, however, Albania was more negatively perceived in Italy than in Sweden. In both Bologna and Venice, all North African countries were perceived more favorably than Italy's neighbor, Montenegro. In Venice, Albania was perceived slightly more favorably than Algeria and Tunisia, but was ranked lower than all 


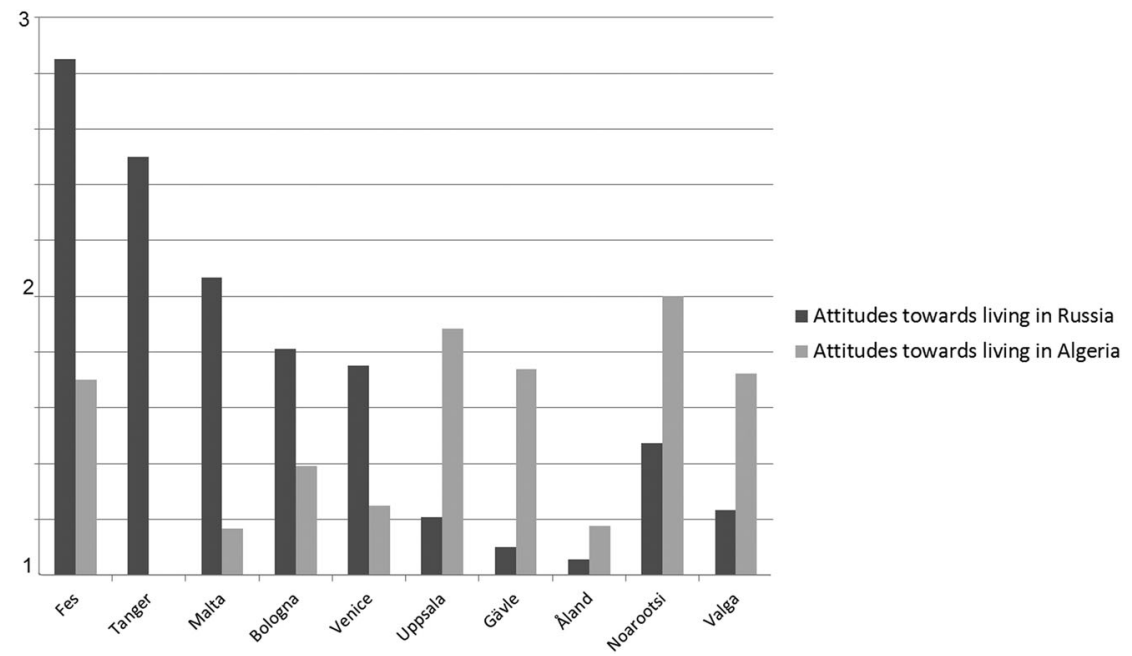

Figure 5. Average perception of Russia and Algeria by students from locations surveyed.

countries in North Africa by Bologna students. In Venice, Egypt and Morocco were considered more popular places to live than Croatia. These examples indicate that the Mediterranean Sea does not function as a simple fault line between North and South in the mental maps of Italian secondary school students, but that the picture is more complex. Moreover, the fall of the Iron Curtain has not automatically lead to a more positive perception of those areas that were once sequestered behind it.

That the Mediterranean is perceived positively in the Baltic Sea region is not surprising. Already Saarinen (1973) noted a "nostalgia for the balmy Mediterranean" on the mental maps of Finnish students, and believed it might be an example of how residents of northern climates looked in general upon areas with more benevolent climate. Another part of this study (to be published in a forthcoming article), where we asked students about their overall perceptions about the Baltic and Mediterranean regions, confirmed that climate was perceived as one of the great advantages of the Mediterranean. Climate might also explain the fact that Sardinia and Corsica appear on the list of the top ten most preferred "countries" of residence in Gävle and Valga (Table 3). That many Mediterranean islands are perceived as countries by the student's is probably related to their insular position as separate geographical entities delimited by their coastlines. Since the ranking was conducted on a blank map, it is possible that the students did not know exactly what islands they were ranking, but awarded them high points anyway based on their attractive location in the Mediterranean.

Nevertheless, this northern gaze on the Mediterranean climate seems to be a constant background factor and cannot explain the changes in mental maps 
Table 3. Top 10 preferred countries as rated by students.

\begin{tabular}{|c|c|c|c|c|c|c|c|c|c|}
\hline \multirow{2}{*}{$\begin{array}{l}\text { Uppsala } \\
\text { UK }\end{array}$} & \multirow[b]{2}{*}{4.3} & \multirow{2}{*}{$\begin{array}{l}\text { Gävle } \\
\text { UK }\end{array}$} & \multicolumn{3}{|c|}{ Åland } & \multicolumn{2}{|l|}{ Noarootsi } & \multicolumn{2}{|l|}{ Valga } \\
\hline & & & 4.6 & UK & 4.7 & Estonia & 4.3 & Italy & 4.3 \\
\hline Italy & 4.1 & Sweden & 4.3 & Sweden & 4.4 & Italy & 4.3 & UK & 4.2 \\
\hline France & 4.1 & France & 3.9 & Norway & 4.3 & UK & 4.2 & Estonia & 4.2 \\
\hline Sweden & 4.0 & Sardinia & 3.8 & Germany & 3.9 & Sweden & 4.2 & Germany & 4.0 \\
\hline Spain & 3.9 & Italy & 3.7 & Denmark & 3.9 & France & 4.1 & France & 4.0 \\
\hline Portugal & 3.3 & Ireland & 3.6 & Finland & 3.6 & Ireland & 3.8 & Spain & 3.8 \\
\hline Norway & 3.2 & Spain & 3.6 & France & 3.6 & Germany & 3.8 & Portugal & 3.8 \\
\hline Switzerland & 2.8 & Norway & 3.4 & Italy & 3.6 & Denmark & 3.7 & Netherlands & 3.5 \\
\hline Germany & 2.7 & Germany & 3.2 & Ireland & 3.5 & Spain & 3.7 & Corsica & 3.5 \\
\hline Ireland & 2.6 & Portugal & 2.9 & Spain & 3.5 & Netherlands & 3.6 & Ireland & 3.5 \\
\hline Bologna & & Venice & & Malta & & Tangier & & $\mathrm{Fez}$ & \\
\hline Spain & 4.3 & UK & 4.5 & Malta & 4.5 & Sweden & 4.4 & Netherlands & 4.6 \\
\hline Italy & 4.2 & Spain & 3.9 & Germany & 4.0 & Morocco & 3.8 & Norway & 4.6 \\
\hline France & 4.2 & Germany & 3.7 & Mallorca & 4.0 & Turkey & 3.7 & Sweden & 4.3 \\
\hline UK & 3.8 & Italy & 3.7 & UK & 4.0 & Germany & 3.4 & Ireland & 4.2 \\
\hline Germany & 3.5 & Denmark & 3.5 & Ireland & 3.9 & UK & 3.3 & UK & 4.0 \\
\hline Portugal & 3.2 & France & 3.4 & Norway & 3.8 & France & 3.2 & Turkey & 3.9 \\
\hline Sweden & 3.0 & Netherlands & 3.1 & Finland & 3.8 & Spain & 2.2 & Morocco & 3.7 \\
\hline Switzerland & 2.9 & Sweden & 3.1 & Switzerland & 3.7 & Algeria & 1.0 & Germany & 3.5 \\
\hline Belgium & 2.8 & Switzerland & 3.0 & Italy & 3.6 & & & France & 3.4 \\
\hline Greece & 2.7 & Ireland & 2.9 & France & 3.6 & & & Saudi Arab. & 3.3 \\
\hline
\end{tabular}

Note: Students ranked countries on the map according to residential desirability on a scale from 1 (lowest) to 5 (highest). In Tangier, only eight countries were ranked by more than five students and included in the table. Some sub-national regions, mostly islands in the Mediterranean, were also ranked as countries by some students. 
that have taken place since the 1960s. It seems, rather, that rising political tensions and nationalist tendencies in the regions may have brought about an atmosphere of distrust among neighbors.

\section{Conclusions}

Our study shows that, despite the end of the Cold War, attempts at region building in the Baltic Sea and the Mediterranean, and increased communication, traffic, and massive migration, the Baltic Sea and the Mediterranean continue to function as borders on mental maps. Most students surveyed had little information about countries on the opposite shore of their neighboring sea, although such knowledge is comparatively better among students from coastal - and particularly island - locations.

The students surveyed from 2014 to 2015 did not display a local preference for nearby countries within their region. While Swedish and Italian students did so in the 1960s, today's students seem to prefer the other country's neighbors to their own. There is a strong tendency to discriminate between countries in one's own region, as reflected in the negative perception of Russia in the Baltic Sea region, and North Africa and the Balkans in the Mediterranean.

Since the 1960s, the tendency to perceive neighbors negatively has come to dominate the earlier tendency for local preference, at least in Sweden and Italy, where direct comparisons can be made. It is plausible that the atmosphere of crisis, threat, and uncertainty at the time of our surveys (20142015) contributed to the prevalent negative attitudes toward neighboring countries. Thus, our quantitative study of mental maps, using concepts and methods from the field of geography, seems to confirm the conclusion earlier drawn by historians, based on textual analyses, that mental maps are sensitive to rapid political changes.

We found that mental maps were in most cases overwhelmingly national. Hopes that the Internet would usher in a new post-national world, just as the printing press paved the way for nationalism, were not confirmed by this study. In the words of Catherine Frost, the anonymous, flexible, low-commitment community on the Internet has thus far not been able to "generate the kind of boundaries and shared meaning that are required for a new system of social and political solidarity" (2006, p. 47).

If the information society had altered mental maps in a direction away from the local and regional, and toward a more global worldview (in which physical distance and location has little importance), we would expect to have found elaborate geographical information maps depicting all corners of the world, particularly among students from countries like Sweden, where there has long been extensive penetration of the Internet and other electronic media. However, this does not correspond with our actual findings: 
Swedish geographical mental maps were extremely national, while the most dispersed geographical information map was found in Fez, Morocco. Nor can the comparatively detailed mental maps of Africa found in Fez be explained by Galtung's theory of information hierarchies, according to which little information should pass from one Third World country to another.

Our findings are difficult to explain without recognizing that mental maps are not simply based upon the reception of information from the surrounding world, but upon an active search and interpretation of information. Reflexes of information selection, such as the strength of one's national or Eurocentric preconceptions, seem more important in determining the place names one learns - and retrieves from memory in a survey situation - than potential access to information.

Such preconceptions have probably formed over generations through interplay between spatial and historical factors, as well as deliberate attempts at identity construction. National and Eurocentric identity conceptions have managed to profoundly influence the mental maps of the students in most locations surveyed, while the Baltic Sea and Mediterranean region-building projects have not. In these two regions, Yi-Fu Tuan's 1975 prediction that, unless it assumed political importance, regionalism was unlikely to impress broad layers of the population still holds true.

Since mental maps are not simply based upon the reception of information from the surrounding world, but upon an active search and interpretation of information, seas like the Baltic and the Mediterranean may continue to function as barriers on mental maps, despite the fact that, thanks to modern information technology, they are no longer barriers to information flow in the direct sense of the word. Since students East of the Baltic and South of Mediterranean Seas had more information about the opposite shore than the other way around, Galtung's theory of global information flows might offer an explanation for this continued barrier function. If information flow from periphery to center is weak, as Galtung suggests, this will affect the mental maps in central countries, such as Sweden and Italy, by impairing knowledge of countries at the opposite shore. It is probably a hindrance to the formation of elaborate mental maps of the Baltic Sea and Mediterranean regions that these seas are surrounded by countries which have very different positions in the center-periphery system of information flow.

By revisiting old mental mapping research and comparing it with new survey results, this study has shown that mental maps do undergo significant changes over time, and that these changes are likely associated with political transformations. However, ours is only a first foray into a field that is largely unexplored, and the interpretation of our findings is hampered by the long time period (1966-2014) that has elapsed between the surveys. The major political events that have taken place in the interim make it difficult to link the 
changes in mental maps to any specific occurrence. For example, it is not impossible that the fall of the Iron Curtain did improve perception of countries east of the Baltic Sea, but this effect may be undetectable in 2014, since it was temporary and has been reversed by later developments, such as the war in Ukraine and rising tensions in the Baltic region. To more systematically investigate how stable mental maps are, and how they are affected by political events, would require further mental mapping research, carried out at more frequent intervals.

\section{Notes}

1. The survey also investigated knowledge and attitudes about the history of these countries. These aspects are analysed in Holmén (2017).

2. The limits between the eight colors on the information maps have been set according to the Jenks distribution, which allows optimal differentiation on choropleth maps. This distribution sets divides independently for each map; thus, colors do not represent identical values on all maps.

3. Mental maps from the Eurobroadmap project surveys can be viewed using the online tool "subjective mapper" at http://www.ums-riate.fr/mapper/.

4. The study is described in Gould (1966) and in Gould and (White 1974). However, principal component analysis was used in 1966, and the 1966 illustrations of Italian and Swedish students are based on the first dimension found in the analysis. The illustrations reprinted here are from 1974 and encompass the entire group of students.

\section{Acknowledgements}

I would like to thank my colleagues in the project Spaces of Expectation; participants in the workshop on "Mental Maps: Historical and Social Science Perspectives" held in Stockholm, 12-13 November 2015; and members of the seminar on History of Education at Uppsala University for all of their valuable input.

\section{Disclosure statement}

No potential conflict of interest was reported by the author.

\section{Funding}

This work was supported by the Foundation For Baltic And East European Studies.

\section{Notes on contributor}

Janne Holmén is a researcher at the department of history, Uppsala University, and at Åbo Akademi University. His main research interests are contemporary history, educational history, historiography, island studies, and mental mapping. 


\section{ORCID}

Janne Holmén (D) http://orcid.org/0000-0003-2449-4888

\section{References}

Berg, R., 2014. Denmark, Norway and Sweden in 1814: a geopolitical and contemporary perspective. Scandinavian Journal of History, 39 (3), 265-286.

Braudel, F., 1949. La Méditerranée et le monde méditerranéen à l'époque de Philippe II. Paris: Armand Colin.

Case, D.O., 2002. Looking for information: a survey of research on information seeking, needs, and behavior. San Diego: Academic Press.

Casey, S. and Wright, J., eds., 2008. Mental maps in the era of two world wars. Basingstoke: Palgrave Macmillan.

Casey, S. and Wright, J., eds., 2011. Mental maps in the early cold war era, 1945-1968. Basingstoke: Palgrave Macmillan.

Didelon, C., et al., 2011. Mental maps of students. Vol. 5 [online]. Available from: https://halshs.archives-ouvertes.fr/halshs-00654530 [Accessed 23 May 2015].

Eurobroadmap subjective mapper [online]. Available from: http://www.ums-riate.fr/ mapper/ [Accessed 27 Jan 2016].

Frost, C., 2006. Internet galaxy meets postnational constellation: prospects for political solidarity after the Internet. The Information Society, 22 (1), 45-49.

Galtung, J., 1971. A structural theory of imperialism. Journal of Peace Research, 8 (2), 81-117.

Gerner, K., Karlsson, K., and Hammarlund, A., 2002. Nordens Medelhav. Östersjöområdet som historia, myt och projekt [The Nordic Mediterranean: the Baltic Sea region as history, myth, and project]. Stockholm: Natur och kultur.

Götz, N., 2016. Spatial politics and fuzzy regionalism. The case of the Baltic Sea area. Baltic Worlds, 9 (3), 54-67.

Götz, N., Hackmann, J., and Hecker-Stampehl, J., eds., 2006. Die Ordnung des Raums. Mentale Landkarten in der Ostseeregion. Berlin: Berliner Wissenschafts-Verlag.

Gould, P., 1966. On mental maps. Ann Arbor: University of Michigan.

Gould, P., 1975a. People in information space: the mental maps and information surfaces of Sweden. Lund: Lund Studies in Geography.

Gould, P., 1975b. Acquiring spatial information. Economic Geography, 51 (2), 87-99.

Gould, P. and White, R., 1974. Mental maps. Harmondsworth: Pelican.

Grassland, C., 2012. Eurobroadmap. Project final report. European commission. http://cordis.europa.eu/docs/results/225260/final1-final-report-23-juillet.pdf.

Hägerstrand, T., 1953. Innovationsförloppet ur korologisk synpunk [Innovation diffusion as a spatial process]. Lund: Gleerup.

Hannes, E., et al., 2012. Mental maps and travel behaviour: meanings and models. Journal of Geographical Systems, 14 (2), 143-165.

Holmén, J., 2017. Mapping historical consciousness: mental maps of time and space among secondary school students from ten locations around the Baltic and Mediterranean Seas. Journal of Autonomy and Security Studies, 1 (1), 46-75.

Jackson, T.N., 2009. Ways on the 'mental maps' of medieval Scandinavians. In: W. Heizmann, K. Böldl, and H. Beck, eds. Analecta septentrionalia: Beiträge zur nordgermanischen Kultur- und Literaturgeschichte. Berlin: de Gruyter, 211-220.

Klinge, M., 1995. Itämeren maailma [The Baltic Sea world]. Helsinki: Otava.

Lynch, K., 1970. The image of the city. Cambridge: MIT Press. 
Madaleno, I.M., 2010. How do remote southern hemisphere residents perceive the world? Mental maps drawn by East Timorese and Mozambican islanders. Scottish Geographical Journal, 126 (2), 112-136.

Rajaram, P.K. and Grundy-Warr, C., 2007. Introduction. In: P.K. Rajaram and C. Grundy-Warr, eds. Borderscapes: Hidden geographies and politics at territory's edge. Minneapolis: University of Minnesota Press, ix-xl.

Saarinen, T., 1973. Student views of the world. In: R.E. Downs and D. Stea, eds. Image and environment. Cognitive mapping and spatial behavior. London: Edward Arnold, 148-161.

Sassen, S., 2002. Towards post-national and denationalized citizenship. In: E.F. Isin and B.S. Turner, eds. Handbook of citizenship studies. London: Sage, 277-291.

Thill, J.-C. and Sui, D.Z., 1993. Mental maps and fuzziness in space preferences. The Professional Geographer, 45 (3), 264-276.

Thomas, M., ed., 2011. The French colonial mind. Vol. 1. Mental maps of empire and colonial encounters. Lincoln: University of Nebraska Press.

Tournadre, J., 2014. Anthropogenic pressure on the open ocean: the growth of ship traffic revealed by altimeter data analysis. Geophysical Research Letters, 41 (22), 7924-7932.

Tuan, Y-F., 1975. Place: an experiential perspective. Geographical Review, 65 (2), 151-165. 